\title{
Conventional and organic cropping systems at Suitia V: Cereal diseases
}

\author{
ASKO O. HANNUKKALA ${ }^{1}$ and EEVA TAPIO ${ }^{2}$ \\ 1 Institute of Plant Protection, Agricultural Research Centre \\ SF-31600 Jokioinen, Finland \\ ${ }^{2}$ Department of Plant Pathology, University of Helsinki \\ SF-00710 Helsinki, Finland
}

\begin{abstract}
The occurrence of diseases on barley and winter wheat was surveyed in a field experiment comparing four conventional and four organic cropping systems in 1982-88. On barley, foliar diseases were of minor importance regardless of the cropping system. On winter wheat, powdery mildew (Erysiphe graminis), yellow rust (Puccinia striiformis) and leaf blotch (Septoria nodorum) were more prevalent in conventional than in organic cropping systems. Root and foot rot diseases (Bipolaris sorokiniana, Fusarium spp. and Gaeumannomyces graminis) were frequent on barley and winter wheat in each cropping system. B. sorokiniana infected stem bases and roots of barley more frequently in organic than in conventional cropping systems. During the first years of the study, a serious epidemic of G. graminis was recorded in certain organic cropping systems.
\end{abstract}

Index words: Hordeum vulgare, Triticum aestivum, cropping systems, Erysiphe graminis, Puccinia striiformis, Septoria nodorum, Fusarium avenaceum, Fusarium culmorum, Cochliobolus sativus, Gaeumannomyces graminis, foliar diseases, root rot, foot rot, cereals

\section{Introduction}

Control of diseases in organic farming is primarily preventative rather than curative. Giving up fungicides makes organic cropping systems vulnerable to certain diseases, especially during the conversion period. Diseases can be controlled by carefully planned, diverse crop rotation, balanced nutrient supply and by use of resistant varieties (MARLAND 1989).
In 1982, when the present study was started, seed dressing was the only widely adapted means of chemical disease control on spring sown cereals in conventional farming in Finland (Tiittanen and Blompvist 1983). Seed treatment is mainly targeted against loose smut (Ustilago nuda (Jens.) Rostrup f.sp. hordei Schaffnit and $U$. nuda (Jens.) Rostrup f.sp. tritici Schaffnit), barley stripe (Pyrenophora graminea Ito \& Kuribay.) and seedling 
blights (Fusarium spp. and Bipolaris sorokiniana (Sacc.) Shoem.), teleomorph Cochliobolus sativus (Ito \& Kuribay.) Drechsl.: Dast.) (VANHANEN 1981).

In the 1980s, leaf infecting diseases, powdery mildew (Erysiphe graminis DC.: Mérat) on barley and wheat, leaf blotch (Septoria nodorum (Berk.) Berk) on wheat, net blotch (Pyrenophora teres Drechsl.) and scald (Rhynchosporium secalis (Oud.) J.J. Davis) on barley have caused considerable damage in Finland (KURTTO 1986). In conventional farming they are controlled by fungicides. Also, moderately resistant cultivars are available.

Soil-borne root and foot rot diseases, $B$. sorokiniana, Fusarium culmorum (W.G. Sm.) Sacc., F. avenaceum (Fr.) Sacc., (teleomorph, Gibberella avenacea R.J. Cook), Gaeumannomyces graminis (Sacc.) von Arx \& Olivier and Rhizoctonia spp., are common especially in conventional cereal-intensive cropping in Southern Finland (MÄKELÄ and PARIKKA 1980). They are controlled by seed dressing, crop rotation and management of energy resources in soil (GARRET 1970). Organic amendments to soil increase the microbial activity, thus frequently decreasing soil-borne diseases. Cereal root rot pathogens are able to colonize organic substrates incorporated into soil, which is occasionally reported to increase their inoculum potential (LINDERMAN 1989).

Very few studies comparing conventional and organic farming systems deal with disease problems (LAMPKIN 1986). The objective of this study was to survey cereal diseases in different conventional and organic cropping systems (HannukKala et al. 1990), with special emphasis on foot and root rot diseases.

\section{Material and methods}

Diseases on barley and wheat were surveyed in a field experiment comparing four conventional and four organic cropping systems. The conventional cropping systems were managed with high chemical inputs, while no chemical fertilisers or crop protection were allowed in the organic cropping systems. The detailed experimental design is given by HANNUKKALA et al. (1990) pp. 295-307 in this issue. The cropping systems, outlines of their fertilisation and the symbols used in the text and tables are:

\section{Conventional cropping}

$\mathrm{A} 1$ = barley monoculture, $\mathrm{N}-\mathrm{P}-\mathrm{K}$ fertilisation A2 = cereal production, N-P-K fertilisation

A3 = diverse plant production, N-P-K fertilisation

$\mathrm{B}=$ cattle farm, N-P-K fertilisation and slurry

\section{Organic cropping}

$\mathrm{C} 1=$ plant production, plant material composted

$\mathrm{C} 2$ = plant production, plant material not composted

D1 $=$ cattle farm, slurry composted

D2 = cattle farm, slurry not composted

The occurrence of diseases on barley was studied in 1982, 1985 and 1988, when barley was grown in all cropping systems. Diseases on winter wheat were surveyed in 1983 and 1986 , respectively. The incidence of smuts and of foliar diseases was checked visually every second week until growth stage 83 (ZADOCKS et al. 1974). If more than approximately $1 \%$ of plants had symptoms on their leaves, a randomized sample of $50-100$ plants was collected from each plot. The diseased leaf area of three upper leaves of individual plants was estimated using the assessment keys of JAMES (1971).

The occurrence of root and foot rot diseases was analysed at growth stages 75 (milk stage) and 95 (harvest) (ZADOCKS et al. 1974). A randomized sample of $50-200$ plants was collected from each plot. Plants were washed under running tap water and rated for disease. Stem bases were classified healthy, lesioned and brown/black. The root rot severity assessment was based on the percentage of discoloured root-area in the uppermost $5 \mathrm{~cm}$ of the root system. Plants were classified in six 
categories according to the method of JENSEN and JøRgensen (1973): $0=$ roots without discoloration; $1=0.1-10 \% ; 2=11-25 \% ; 3=$ $26-50 \% ; 4=51-75 \%$; and $5=76-100 \%$ discoloured root mass. The root rot severity (RS) was finally calculated with the formula:

$\mathrm{RS}=\frac{0 \times \mathrm{N} 0+1 \times \mathrm{N} 1+2 \times \mathrm{N} 2+3 \times \mathrm{N} 3+4 \times \mathrm{N} 4+5 \times \mathrm{N} 5}{5 \times(\mathrm{N} 0+\mathrm{N} 1+\mathrm{N} 2+\mathrm{N} 3+\mathrm{N} 4+\mathrm{N} 5)} \times 100$

where N0 to N5 are numbers of observations in each category.

Diseased stem bases were cut into pieces about $2 \mathrm{~cm}$ long. They were surface sterilised for 1 minute in $1 \%$ sodiumhypochlorite $(\mathrm{NaOCl})$ solution, 10 seconds in $96 \%$ ethanol and rinsed with sterile distilled water. Surface sterilised stem pieces were left to dry for 3-4 hours and transferred to CMA (Cornmeal agar, Difco Laboratories, Michigan, USA) to which $200 \mathrm{ppm}$ streptomycin sulfate was added to inhibit bacterial growth. Plates were incubated at room temperature $\left(18-20^{\circ} \mathrm{C}\right)$ at diffuse daylight and examined for fungal identification after 7 and 20-25 days. When necessary, tips of fungal hypha were transferred to PDA (Potato dextrose agar, Difco laboratories, Michigan, USA) for further identification.

To identify the fungi inhabiting the root system, a randomized sample of 50 root pieces about $1 \mathrm{~cm}$ long was taken from plants after disease rating. Root pieces were surface sterilised, transferred to CMA, incubated and examined as described above. In 1985 and 1986, an additional root sample (50 root pieces/plot) was surface sterilised as above and transferred to media selective to Bipolaris sorokiniana (REIS 1983). Another additional sample of 50 root pieces/plot was surface sterilised with silver nitrate solution ( $\left.1 \% \mathrm{AgNO}_{3}\right)$ according to the method of Stetter and Leroul (1979) and incubated in media selective for Gaeumannomyces graminis (JUHNKE et al. 1984).

The germination of harvested seed and fungi associated with germinated and ungerminated seed was analysed by a blotter test (de TEMPE 1963).
The experimental data were analysed using SPSS Inc. and SAS Institute Inc. statistical packages. The complete model for testing differences between means and frequencies consisted of four main factors: group of cropping systems (conventional vs. organic cropping), individual cropping systems nested within group (treatment), year (repeated observation) and replicates (blocks) (HANNUKKALA et al. 1990). Individual cropping systems were often ignored, and the final model included three main factors: group of cropping systems, year and replicate. The models were tested either using the analysis of variance procedure and the Tukey test or the maximum likelihood method to estimate parameters for log-linear models (CATMOD-procedure for categorical data modeling, SAS Institute Inc.), depending on the type of data.

\section{Results}

\section{Diseases on barley}

Seed-borne diseases, loose smut and barley stripe, were detected in the experiment only occasionally. The average number of diseased plants was less than 1 per 10 square metres in all cropping systems. The seed harvested from conventional cropping systems germinated well. In organic cropping systems, the percentage of normally germinated seed was considerably lower in 1985 and 1988, which indicates high infestation of seed with $B$. sorokiniana (Table 1).

There was only a trace of foliar diseases in years when barley was grown in all cropping systems: net blotch and scald were found occasionally regardless of the cropping system. In 1984, stem rust (Puccinia graminis Pers.) and brown rust (Puccinia recondita Rob.: Desm.) attacked barley late in the growing season. At growth stage 75, $42 \%$ of stems were infected. In 1987, when barley was grown only in conventional cropping systems, there was a heavy attack of net blotch.

On the average, $35 \%$ of barley plants showed symptoms on stem bases. In 1982, 
Table 1. Germination and pathogenic contamination of harvested barley seed in conventional and organic cropping.

\begin{tabular}{lccc}
\hline & $\begin{array}{c}\text { Conventional } \\
\text { cropping }\end{array}$ & $\begin{array}{c}\text { Organic } \\
\text { cropping }\end{array}$ & $\begin{array}{c}\text { Statistical } \\
\text { significance }\end{array}$ \\
\hline Year & Normally germinated barley seed $\%$ & NS \\
1982 & 97 & 96 & $* * *$ \\
1985 & 90 & 81 & $* * *$ \\
1988 & 91 & 78 & $* * *$ \\
Pathogens: & Pathogenic contamination of seed $\%$ & 19 & $* * *$ \\
Bipolaris sorokiniana & 6 & 19 & \\
Fusarium spp. & 38 & & \\
\hline
\end{tabular}

Table 2. Occurrence of foot rot and foot rot pathogens, Bipolaris sorokiniana, Fusarium avenaceum and $F$. culmorum, on barley in conventional and organic cropping systems at growth stage 75 in 1982, 1985 and 1988.

\begin{tabular}{|c|c|c|c|c|}
\hline $\begin{array}{l}\text { Cropping } \\
\text { system (CS) }\end{array}$ & $\begin{array}{l}\text { Year } \\
1982\end{array}$ & 1985 & 1988 & Mean \\
\hline \multicolumn{5}{|c|}{$\%$ of plants with foot rot symptoms } \\
\hline Conventional (C) & 40 & 29 & 68 & 46 \\
\hline \multirow[t]{2}{*}{ Organic (O) } & 54 & 34 & 47 & 45 \\
\hline & \multicolumn{4}{|c|}{$\%$ of diseased stem bases infected with $B$. sorokiniana } \\
\hline Conventional (C) & 13 & 12 & 8 & 11 \\
\hline \multirow[t]{2}{*}{ Organic (O) } & 39 & 40 & 23 & 34 \\
\hline & \multicolumn{4}{|c|}{$\%$ of diseased stem bases infected with $F$. avenaceum and $F$. culmorum } \\
\hline Conventional (C) & 31 & 9 & 97 & 46 \\
\hline Organic $(\mathrm{O})$ & 33 & 15 & 74 & 41 \\
\hline
\end{tabular}

Chi-squares for factors included in the best log-linear model:

$$
\text { variable: } \quad \text { foot rot } \%
$$

Year (Y)

Group of cropping systems (GCS)

Interaction $\mathrm{Y} \times \mathrm{GCS}$

$316.2^{* * *}$
0.4 ns
$249.5^{* * *}$

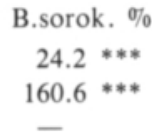

B.sorok. \%
$24.2^{* * *}$
$160.6^{* * *}$

Fusarium \% $253.0^{* * *}$ $10.6^{*}$ $37.1^{* * *}$ foot rots were more common in organic than in conventional cropping $\left(\chi^{2}=206.03^{* * *}\right)$; in 1985 there was no statistically significant difference between cropping systems $\left(\chi^{2}=\right.$ 6.87 ), while in 1988 , stems in organic cropping were healthier than in conventional cropping $\left(\chi^{2}=113.07^{* * *}\right)$. Common root rot pathogens, Bipolaris sorokiniana, Fusarium avenaceum and $F$. culmorum were isolated from diseased stems. B. sorokiniana was more frequent in organic than in conventional cropping. In 1988, Fusarium spp. were more frequent in conventional than in organic cropping $\left(\chi^{2}=36.60^{* * *}\right)$ (Table 2). Gaeumannomyces graminis and Rhizoctonia spp. were found to some extent in 1982, but they were very rare in 1985 and 1988. In 1988, Michro- dochium nivale (Fr.) Samu \& Hall (Gerlachia nivalis (Ces.: Sacc.) W. Gams \& E. Müll.) was found occasionally.

The root rot severity measured as root discoloration was clearly affected by the group of cropping systems in 1985 and 1988 but not in 1982. In 1985, roots were healthier in conventional cropping, while in 1988 they were healthier in organic cropping. No differences in root discoloration between individual cropping syștems within organic or conventional cropping could be shown (F-values 1982: 1.68 ns, 1985: 1.78 ns, 1988: 4.07*) (Table 3). Statistically significant differences in root discoloration between replicates were found $(\mathrm{F}$ value $\left.5.97^{* * *}\right)$.

Essentially the same pathogens were iso- 
Table 3. Root rot severity (0-100) and number of Bipolaris sorokiniana, Fusarium spp. and Gaeumannomyces graminis per $\mathrm{m}$ of root of barley in conventional and organic cropping at growth stage 95 in 1982,1985 and 1988.

\begin{tabular}{|c|c|c|c|c|}
\hline $\begin{array}{l}\text { Group of cropping } \\
\text { systems }\end{array}$ & $\begin{array}{l}\text { Year } \\
1982\end{array}$ & 1985 & 1988 & Mean \\
\hline & \multicolumn{4}{|c|}{ Root rot severity $(0-100)$} \\
\hline Conventional & $27^{\mathrm{a}}$ & $23^{a}$ & $14^{a}$ & $21^{\wedge}$ \\
\hline \multirow[t]{2}{*}{ Organic } & $30^{\mathrm{a}}$ & $33^{b}$ & $5^{b}$ & $22^{\mathrm{A}}$ \\
\hline & \multicolumn{4}{|c|}{ Number of $B$. sorokiniana infections per $\mathrm{m}$ root } \\
\hline Conventional & $25^{\mathrm{a}}$ & $50^{\mathrm{a}}$ & $2^{\mathrm{a}}$ & $26^{\wedge}$ \\
\hline \multirow[t]{2}{*}{ Organic } & $64^{b}$ & $94^{b}$ & $15^{b}$ & $57^{\mathrm{B}}$ \\
\hline & \multicolumn{4}{|c|}{ Number of Fusarium spp. infections per m root } \\
\hline Conventional & $65^{\mathrm{a}}$ & $65^{\mathrm{a}}$ & $9^{\mathrm{a}}$ & $46^{A}$ \\
\hline \multirow[t]{2}{*}{ Organic } & $73^{a}$ & $61^{b}$ & $16^{\mathrm{b}}$ & $50^{4}$ \\
\hline & \multicolumn{4}{|c|}{ Number of $G$. graminis infections per $\mathrm{m}$ root } \\
\hline Conventional & $16^{a}$ & $27^{a}$ & $7 a$ & $16^{\wedge}$ \\
\hline Organic & $36^{\mathrm{b}}$ & $23^{a}$ & $4^{a}$ & $21^{A}$ \\
\hline
\end{tabular}

Means with the same letter do not differ statistically $(\mathrm{p}=0.005)$ :

$a-b$ comparison of two means within one year

$\mathrm{A}-\mathrm{B}$ comparison of grand means of cropping system

lated from roots as from stem bases. The number of $B$. sorokiniana infections was considerably higher in organic than in conventional cropping each year (F-values 1982: 54.32***, 1985: 110.02***, 1988: 28.90***). The roots were most severely infected in the cropping systems $\mathrm{C} 2$ and D2, where uncomposted plant material was applied (Fig. 1). Yearly variation in the number of Fusarium spp. and $G$. graminis infections was considerable (F-values $379.57^{* * *}$ and $54.97^{* * *}$, respectively). The highest counts for both fungi were recorded in 1982 and 1985. Cropping systems usually had no statistically significant effect on the occurrence of Fusarium spp. and G. graminis. However, in 1982, G. graminis was recovered twice as often on roots in organic as in conventional cropping ( $\mathrm{F}$-value 7.14***) (Table 3).

\section{Diseases on winter wheat}

Loose smut and other primarily seed-borne diseases were rare in all cropping systems. In 1983, powdery mildew attacked winter wheat in conventional cropping systems, where more than $50 \%$ of plants had symptoms on at least one of the three upper leaves at growth stage
65 . The mean leaf area covered by the pathogen was approximately $0.5 \%$. In organic cropping systems, less than $5 \%$ of plants had mildew on one of the three upper leaves (Fig. 2).

In 1986, leaf blotch and rusts (Puccinia striiformis Westend. and $P$. recondita) were common in winter wheat, while powdery mildew was of minor importance. The average percentage of plants with one of the three upper

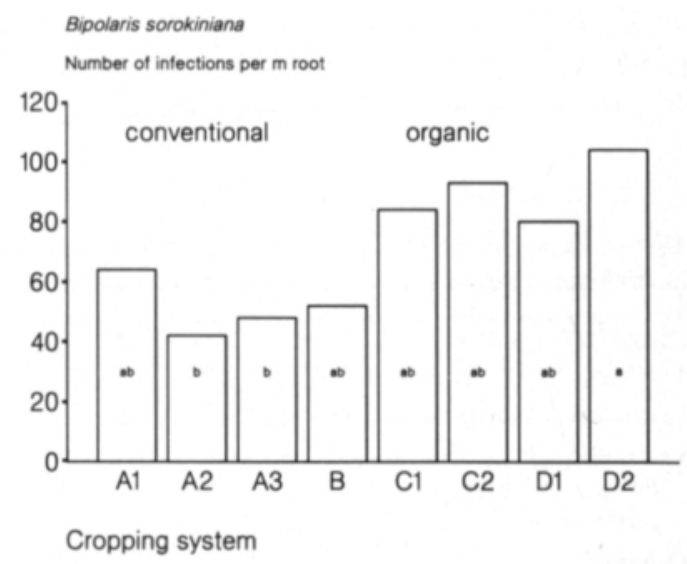

Fig. 1. Occurrence of common root rot (Bipolaris sorokiniana) on barley roots in conventional and organic cropping systems at growth stage 95 in 1982-88. Bars with the same letter do not differ statistically $(p=0.005)$. 


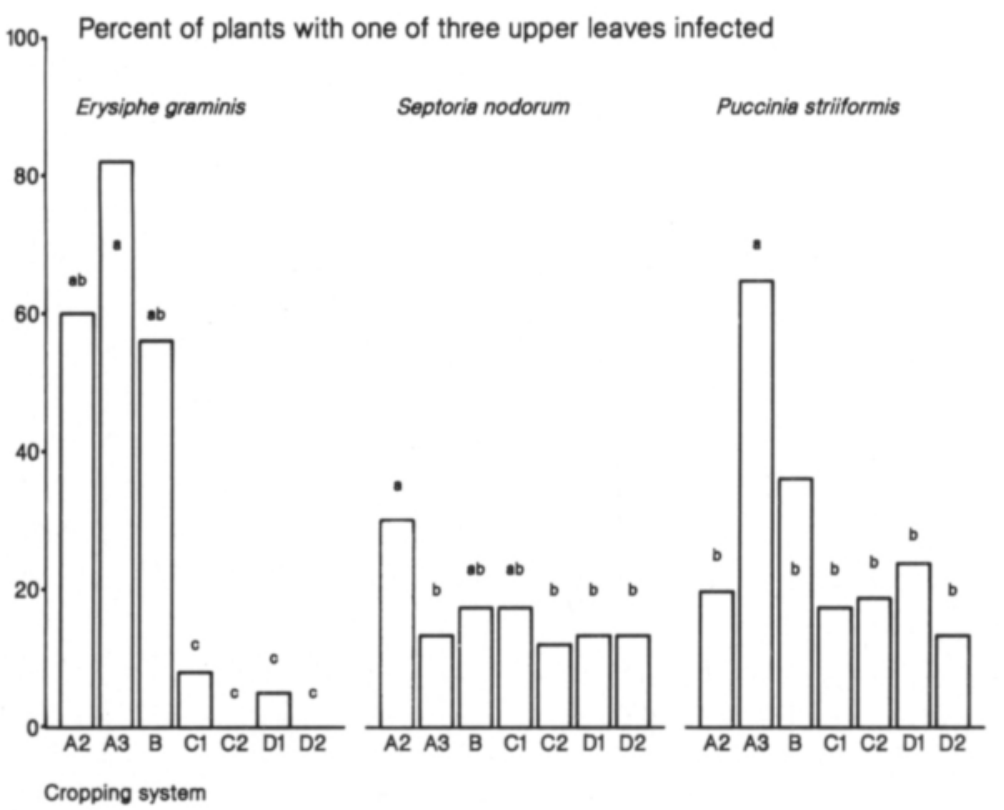

Fig. 2. Occurrence of powdery mildew (in 1983), leaf blotch and yellow rust (in 1986) on three upper leaves of winter wheat in conventional and organic cropping systems. Bars with the same letter do not differ statistically $(p=0.005)$.

leaves infected with leaf blotch and yellow rust was higher in conventional than in organic cropping systems. Leaf blotch was most prevalent in cropping system A2, where spring wheat had been grown in 1984. The highest counts of yellow rust were recorded in cropping systems A3 and B, but the deviation between individual plots was considerable. Brown rust infected, on the average, $10 \%$ of plants in all cropping systems (Fig. 2).

Foot rots, caused mainly by $F$. avenaceum and $F$. culmorum, were more frequent in conventional than in organic cropping systems (30 \% and $23 \%$ respectively, $\chi^{2}=17.93^{* * *}$ ). Significant variation in the occurrence of foot rots between years $\left(\chi^{2}=347.69^{* * *}\right)$ as well as between replicates $\left(\chi^{2}=16.41^{* * *}\right)$ was obvious.

Average root rot severity was much higher in 1983 than in 1986 (23 and 8, respectively, $\left.\mathrm{F}=889.59^{* * *}\right)$. Cropping systems had no statistically significant effect on root rot severity $(\mathrm{F}=0.05)$. The most common pathogens isolated from roots were $F$. avenaceum, F. culmorum and G. graminis. Also B. sorokiniana and Rhizoctonia-species were found occasionally. In 1983, G. graminis was extremely frequent on roots in organic plant production ( $\mathrm{C} 1$ and $\mathrm{C} 2$ ), while the counts were lowest in organic cattle production (D1 and

Table 4. Root rot severity and occurrence of Fusarium spp. and Gaeumannomyces graminis on roots of winter wheat in 1983 and 1986 in conventional and organic cropping systems at growth stage 95.

\begin{tabular}{|c|c|c|c|c|c|c|}
\hline \multirow{2}{*}{$\begin{array}{l}\text { Group of cropping } \\
\text { systems }\end{array}$} & \multicolumn{2}{|c|}{ Root rot severity } & \multicolumn{2}{|c|}{ Fusarium \% } & \multicolumn{2}{|c|}{ G. graminis $\%$} \\
\hline & 1983 & 1986 & 1983 & 1986 & 1983 & 1986 \\
\hline \multirow{3}{*}{$\begin{array}{l}\text { Conventional } \\
\text { plant production } \\
\text { cattle farm }\end{array}$} & & & & & & \\
\hline & $20^{\mathrm{a} *}$ & $8^{a}$ & $43^{a}$ & $26^{a}$ & $53^{a}$ & $18^{a}$ \\
\hline & $19^{a}$ & $7^{a}$ & $33^{\mathrm{a}}$ & $22^{a}$ & $27^{b}$ & $25^{a}$ \\
\hline \multicolumn{7}{|l|}{ Organic } \\
\hline plant production & $26^{a}$ & $8^{a}$ & $17^{\mathrm{ab}}$ & $22^{a}$ & $100^{\mathrm{a}}$ & $18^{a}$ \\
\hline cattle farm & $25^{a}$ & $8^{a}$ & $3^{b}$ & $18^{\mathrm{a}}$ & $7^{b}$ & $22^{a}$ \\
\hline
\end{tabular}

* Means with the same letter within one year do not differ statistically $(p=0.005)$. 
D2). Fusarium species were more frequent in conventional than in organic cropping systems $\left(\mathrm{F}=33.11^{* * *}\right)$. In 1986, there were no statistically significant differences in the occurrence of root rot pathogens between individual or any groups of cropping systems (Table 4).

\section{Discussion}

Seed-borne diseases were of minor importance during the experiment even in organic cropping systems where no chemical seed dressing was made. This is probably due to the high quality of commercial seed used throughout the experiment. Poor germination and severe pathogenic contamination of seed harvested in organic cropping systems indicate increasing risk of seed-borne diseases on actual organic farms where domestic seed is used year after year.

The occurrence of foliar diseases is highly dependent on weather during the growing season. Disease incidence was too low to make any comparisons between cropping systems in the relatively dry summers of 1982, 1985 and 1988 (HannUKKALA et al. 1990), when barley was grown in all of them. The foliar diseases attacked winter wheat more seriously in conventional than in organic cropping. In 1983, the control threshold of powdery mildew was exceeded (KuRTTo 1986). The crop was, however, not sprayed, because no fungicide was registered for that purpose in Finland. More severe epidemic of powdery mildew in conventional than organic farming has been reported by El Titi and LANDES (1988). In their study, higher Septoria-blotch infestation was recorded in organic than in conventional farming. Susceptibility of plants to foliar diseases is known to increase with an increasing rate of nitrogen application (HUBER and WATSON 1974). The lower incidence of powdery mildew in organic cropping can also be explained by the beneficial effect of slow-acting nitrogen fertilisers (EL TITI 1986).

The occurrence of soil-borne foot and root rot diseases and pathogens was of roughly the same level as that reported by MÄKELÄ and PARIKKA (1980) in conventional farms in Southern Finland. During the first two years of the experiment, when the crop sequences were principally the same in all cropping systems, the heavier foot and root rot infestation occurring in organic cropping systems was probably caused by the low nutrient level and type of manures applied. Towards the end of the experiment, the differences between cropping systems decreased, which indicates that the effects of diverse crop sequences compensated for the effects of nutrient deficiency in organic cropping.

Nutrient deficiency has been reported to increase $G$. graminis and B. sorokiniana (Huber 1981). Severe injuries caused by $G$. graminis have been reported after green manuring crops, such as subterranean clover (BUTLER 1959). Extremely high counts of the pathogen were also recorded in this study on winter wheat in organic cropping in 1983, when the preceding crop was barley undersown with subterranean clover, while counts were low in organic cropping where slurry was applied. However, the effects of organic nitrogen on the survival of G. graminis are very complicated (HUBer 1981). The high infestation of $B$. sorokiniana in organic cropping systems can partly be explained by the use of barley straw as the raw material for the organic manure applied. The status of fungal contamination of the straw was not analysed.

The results of the experiment indicate that the main problem in organic cropping is how to ensure an adequate nutrient supply. As no chemicals are used for seed dressing, it is crucial to pay special attention to the quality of seed. Also the organic amendments may increase disease incidence, a fact which emphasises the importance both of hygiene and of the origin of the raw materials used for organic manures.

Acknowledgement. We wish to thank Mr Pentti Heinänen, Mrs Pirkko Korhonen and Mrs Tuula Laine for technical assistance during the study. 


\section{References}

BUTLER, F.C. 1959. Saprophytic behavior of some cereal root rot fungi IV. Saprophytic survival in soils of high and low fertility. Ann. Appl. Biol. 47: 28-36.

EL Tıтı, A. 1986. Management of cereal pests and diseases in integrated farming systems. Brit. Crop Protect. Conf. Pest Dis. 1986: 147-155.

- \& LANDES, H. 1988. The integrated farming system of Lautenbach: a practical contribution towards sustainable agriculture in Europe. Proc. Conf. Sustainable Agric. Ohio. 23-27.9.1988.

Garrett, S.D. 1970. Pathogenic root-infecting fungi. 294 p. Cambridge Univ. Press, London.

Huber, D.M. 1981. The role of nutrients and chemicals. P. 317-352 in Asher, M.J.C. and Shipton, P.J. (eds.): Biology and control of take-all. Academic Press. London, New York, Toronto, Sydney, San Francisco.

- \& W ATSON, R.D. 1974. Nitrogen form and plant disease. Ann. Rev. Phytopath. 12: 139-165.

JAMES, C.W. 1971. An illustrated series of assessment keys for plant diseases, their preparation and usage. Can. Pl. Dis. Surv. 51: 39-65.

Jensen, H.P. \& Jorgensen, J.H. 1973. Reactions of five cereal species on the take-all fungus (Gaeumannomyces graminis) in the field. Phytopathol. Z. 78: 193-203.

Juhnke, M.E., Mathre, D.E. \& Sands, D.C. 1984. A selective medium for Gaeumannomyces graminis var. tritici. Pl. Dis. 68: 233-236.

Hannukkala, A.O., Korva, J. \& Tapio, E. 1990. The cropping systems at Suitia: The experimental design. J. Agric. Soc. Finl. 62: 295-307.

KURTTo, J. 1986. Milloin viljojen lehtilaikkujen torjunta kannattaa. Koetoim. ja Käyt. 43: 37.
LAMPKIN, N. 1986. Fallbeispiele zum Öko-Landbau. Studien über biologische Landbausysteme in Westeuropa und Nordamerika - eine Literaturübersicht zu Fragen der Ökonomie, Qualität, Ökologie, Vermarktung und Energiebilanz. P. 237-269 in Vogtman, H., Boehncke, E. \& Fricke, I. (eds.): Öko-Landbau eine weltweite Notwendigkeit.

Linderman, R.G. 1989. Organic amendments and soilborne diseases. Can. J. Pl. Path. 11: 180-183.

Marland, A. 1989. An overview of organic farming in the UK. Outlook Agric. 18: 24-27.

MÃKelĀ, K. \& PARIKKA, P. 1980. Root and foot rot diseases of cereals in Southern Finland 1975-1978. Ann. Agric. Fenn. 19: 223-253.

ReIs, E.M. 1983. Selective medium for isolating Cochliobolus sativus from soil. Pl. Dis. 67: 68-70.

Stetter, S. \& Leroul, N. 1979. Ensidig bygdyrkning. II. Indflydelsen på røddernes svampeflora. Tidsskr. Pl.avl. 83: 50-72.

TEMPE, J. de 1963. The blotter method for seed health testing. Proc. Intern. Seed. Test. Ass. 28, 1: 133-151.

TIItTAnen, K. \& Blomevist, H. 1983. Torjunta-aineiden myynti Suomessa 1982. (Sales of pesticides in Finland in 1982, summary). Kemia-Kemi 10 (9): 759-762.

VANHANEN, R. 1981. Experiments with non-mercury seed dressings on spring cereals. Ann. Agric. Fenn. 20: 89-91.

Zadoks, J.C., Chang, T.T. \& KonzaK, C.F. 1974. A decimal code for the growth stages of cereals. Weed Res. 14: $415-421$.

Ms received September 14, 1990 


\section{SELOSTUS}

\section{Suitian viljelyjärjestelmät V: Viljojen taudit}

\author{
Asko Hannukkala ${ }^{1}$ ja Eeva Tapio ${ }^{2}$ \\ 1 Kasvinsuojelun tutkimuslaitos, \\ Maatalouden tutkimuskeskus, \\ 31600 Jokioinen \\ 2 Kasvipatologian laitos, \\ Helsingin yliopisto, \\ $00710 \mathrm{Helsinki}$
}

Suitian koetilalla järjestetyssä kenttäkokeessa vertailtiin vuosina 1982-1988 neljāă tavanomaista ja neljäả luonnonmukaista viljelyjärjestelmảă. Kasvitautien esiintymistă eri viljelyjärjestelmissă selvitettiin ohralla vuosina 1982, 1985 ja 1988 sekă syysvehnällă vuosina 1983 ja 1986 . Kasvustot tarkastettiin kahden viikon välein ja mikäli yli $1 \%$ kasveista oli sairastunut, kerättiin kaikista koeruuduista 100 kasviyksilön otos, josta arvioitiin tautien peittämả ala kolmesta ylimmästä lehdestă. Tyvi- ja juuristotautien runsaus selvitettiin kasvuasteella 75 ja 95 kerảämällă $50-200$ kasvin otos. Kasveista arvioitiin silmävaraisesti tyvien ja juuriston kunto ja määritettiin taudinaiheuttajalajisto laboratorioviljelmien perusteella. Siemensadosta tehtiin idätyskokeet ja maaăritettiin siemenissă esiintyvă taudinaiheuttajalajisto.

Siemenlevintäisiä tauteja, lentonokea ja ohranviirutautia todettiin kasvustoissa hyvin văhän. Peittauksesta luopuminen luonnonmukaisissa viljelyjärjestelmissă ei johtanut siemenlevintăisten tautien lisääntymiseen, sillă kokeen kylvösiemenenä käytettiin vuosittain hyvälaatuista kauppasiementă. Siemensadosta tehdyissă idătyksissä luonnonmukaisesti viljeltyjen siementen itävyys oli selvăsti heikompi kuin tavanomaisesti viljeltyjen. Lisäksi luonnonmukaisesti viljellyissä siemenissä esiintyi hyvin runsaasti ohrantyvi- ja lehtilaikkutautia (Bipolaris sorokiniana).

Ohra säăstyi lehtiä vioittavien tautien tuhoilta niină vuosina, jolloin ohraa viljeltiin sekä tavanomaisissa ettă luonnonmukaisissa viljelyjärjestelmissă. Yksittäisissă kasveissa todettiin verkkolaikkua (Pyrenophora teres) ja rengaslaikkua (Rhynchosporium secalis) kaikissa viljelyjärjestelmissă. Tavanomaisesti viljellyssă syysvehnässă esiintyi runsaasti hărmaă (Erysiphe graminis) vuonna 1983. Luonnonmukaisesti viljellyssä vehnăssả hărmaaả todettiin erittăin văhăn. Vuonna 1986 syysvehnăkasvustoissa esiintyi yleisesti ruskolaikkua (Septoria nodorum) ja keltaruostetta (Puccinia striiformis). Tautien esiintymisessă oli erittäin suuria koeruutujen vălisiă vaihteluita, mutta keski- määrin ruskolaikkua ja keltaruostetta todettiin enemmän tavanomaisesti viljellyssä kuin luonnonmukaisesti viljellyssă vehnässă. Ruskolaikku oli erityisen yleinen tavanomaisessa viljavaltaisessa viljelyssä, jossa vehnảả oli edellisen kerran viljelty vuonna 1984.

Tyvi- ja juuristotauteja esiintyi runsaasti sekă ohralla ettă syysvehnällă. Tutkimuksen alkuvuosina tyvi- ja juuristotauteja esiintyi enemmän luonnonmukaisissa kuin tavanomaisissa viljelyjärjestelmissă. Viljelyjärjestelmien văliset erot năyttivăt tasoittuvan kokeen jatkuessa. Vuonna 1988 tavanomaisesti viljellyssä ohrassa esiintyi enemmän tyvitauteja ja kasvien juuret olivat huonokuntoisempia kuin luonnonmukaisesti viljellyssă ohrassa. Yleisimmăt tyvitaudinaiheuttajat olivat syysvehnăllă Fusarium avenaceum ja $F$. culmorum. Ohralla esiintyi lisăksi hyvin runsaasti ohrantyvi- ja lehtilaikkua. Kasvien juuristoa vioittivat samat taudinaiheuttajalajit kuin tyviá. Lisăksi ohran ja vehnăn juurissa todettiin yleisesti mustatyvitaudin aiheuttajaa (Gaeumannomyces graminis).

Ohrantyvi- ja lehtilaikkua esiintyi kaikkina tutkimusvuosina selvăsti enemmän luonnonmukaisissa kuin tavanomaisissa viljelyjärjestelmissä. Erityisen runsaana tautia todettiin niissă luonnonmukaisissa jărjestelmissă, joissa kompostoimatonta kasvimateriaalia kăytettiin lannoitteena. Mustatyvitautia esiintyi erityisen runsaasti vuonna 1983 syysvehnässä. Eniten tautia todettiin luonnonmukaisissa viljelyjärjestelmissă, joissa ennen syysvehnäă viljeltiin ohraa aluskasvina maa-apila.

Tutkimuksen perusteella kasvitautien aiheuttamia ongelmia luonnonmukaisessa viljelyssä voidaan pităă melko vähäisenă verrattuna vaikeuksiin, jotka liittyvăt riittăvăn kasvinravitsemuksen jărjestämiseen. Kylvösiemenen peittaamatta jättäminen edellyttăă, ettă kylvösiemenen terveyteen kiinnitetăăn erityistä huomiota. Lannoitteena käytettăvă eloperäinen aines voi toimia tehokkaana tautien tartuntalăhteenă, joten materiaalin alkuperä ja terveys tulisi selvittăả huolellisesti. 